УДК 351.741:007:316.776(477)

DOI https://doi.org/10.32849/2663-5313/2020.10.14

\title{
Віктор Булаєв,
}

здобувач наукового ступеня доктора філософії (кандидата наук) наукової лабораторії

з проблем превентивної діяльності та запобігання корупиіі

Навчально-наукового інституту № 3

Національної академії внутрішніх справ

\section{ДІЯЛЬНІСТЬ ІНФОРМАЦИЙНИХ СЛУЖБ ОРГАНІВ МВС УКРАЇНИ 3 ПРОФІЛАКТИКИ ПРАВОПОРУШЕНЬ}

Без широкого інформування громадськості про діяльність правоохоронних органів $і$ зворотного зв'язку не може бути ефективної боротьби з правопорушеннями, високого авторитету поліиії у населення. В управлінні сочіальними явищами беруть участь практично всі органи держави в межах своєї компетениії. Розглядати їхню діяльність з позииій системного підходу в частині узгодження зусиль з профілактики правопорушень з виходом на масове охоплення населення неможливо, тому що в иій сфері боротьби з правопорушеннями вони не діють як єдина система, складова частина суб'єкта управління суспільними процесами. Метою статті є визначення діяльності інформаційних служб системи МВС України щодо профілактики правопорушень. У результаті емпіричного дослідження діяльності інформачійних служб системи МВС Украйни щодо профілактики правопорушень визначено, що одним із головних завдань Міністерства внутрішніх справ є створення якісно нової української поліиії, яка б відповідала сучасним світовим стандартам. Партнерські стосунки між поліиією та населенням дістали новий імпульс до розвитку. Основним методом діяльності поліиії щодо забезпечення громадського порядку $\epsilon$ метод переконання. Суть його полягає у впливі на свідомість та поведінку людей з метою формування у них правильних переконань, розуміння необхідності добровільно і сумлінно виконувати вимоги закону та інших правових норм, а зміст становить комплекс різноманітних конкретних заходів $і$ засобів такого впливу. У практичній діяльності полічії ией метод реалізується в різних формах, таких як: правове виховання; постійне інформування населення про стан боротьби з правопорушеннями; агітаиійнороз'яснювальна робота серед населення; застосування заходів заохочення; робота з правопоруиниками, особами з так званих груп ризику. Аналіз діяльності інформачійних служб системи МВС Украӥни щодо профілактики правопорушень показав, що у процесі взаємодії з населенням і засобами масової інформаціі головна увага зосереджена на координачії профілактичної діяльності служб і підрозділів правоохоронних органів інформачійними службами МВС. Під координаиією розуміється узгодженість дій правоохоронних органів у боротьбі з правопорушеннями за метою, часом, місием проведення та програмою з урахуванням компетениії кожного з цих органів щодо вирішення спільних завдань у боротьбі з правопорушеннями в умовах їх функиіонального зв'язку. Поставлена мета досягається вирішенням низки завдань, які $\epsilon$ загальними для всіх органів, що беруть участь у координаиії, і випливають із законів України, Указів Президента, Постанов Уряду України, наказів, розпоряджень МВС України та рішень його Колегї̈. До таких завдань слід віднести: розширення рівня гласності з метою підвищення авторитету правоохоронних органів, зміщнення їхньої репутаиї; об'єднання зусиль підрозділів поліиії, усунення їх роз'єднаності в боротьбі з правопорушеннями з використанням засобів масової інформачії; усунення розпорошення сил у діяльності правоохоронних органів щодо попередження правопорушень.

Ключові слова: інформаційні служби, підрозділи правоохоронних органів, профілактика правопорушень, засоби масової інформації.

Постановка проблеми. Діяльність правоохоронних органів щодо профілактики правопорушень не може бути ефективною без налагодження тісної взаємодії між різними підрозділами самих цих органів, яка здійснюеться в тому числі й інформаційними службами МВС. Без широкого інформування громадськості про діяльність правоохоронних органів і зворотного зв'язку не може бути ефективної боротьби з право- порушеннями, високого авторитету поліції у населення.

В управлінні соціальними явищами беруть участь практично всі органи держави в межах своєї компетенції. Розглядати їхню діяльність 3 позицій системного підходу в частині узгодження зусиль з профілактики правопорушень 3 виходом на масове охоплення населення неможливо, тому що в цій сфері боротьби з правопорушеннями вони 
не діють як єдина система, складова частина суб'єкта управління суспільними процесами. Чого не можна сказати про правоохоронні органи, діяльність яких відзначається системним характером, має єдиний управлінський вплив з боку керівництва вищих органів, координується за окремими напрямами різними спеціальними суб'єктами, зокрема інформаційними службами МВС [1, с. 53]

Стан дослідження. Дослідженням питань управління в правоохоронних органах займалися такі українські вчені: О. М. Бандурка, І. П. Голосніченко, Є. В. Додін, М. М. Дорогих, Р. А. Калюжний, Д. П. Калаянов, А. Т. Комзюк, О. І. Остапенко, В. П. Пєтков, В. М. Плішкін, В. К. Шкарупа та ін. Разом із тим розуміння управлінського процесу в науковій літературі різняться. Як зазначає А. В. Пилипко, управлінський процес це прогнозування, планування, організація, комплектація кадрами, мотивація і контроль, а Г. В. Атаманчук, А. Ф. Мельник розширюють функції управління, вказуючи, що в процесі досягнення результату до і після прогнозування, планування, організації, комплектації кадрами, мотивації і контролю відбувається аналіз і оцінювання управлінської ситуації, а після стадії контролю - узагальнення проведених етапів управлінської діяльності, оцінка нової (результативної) ситуації [2].

Метою статті $€$ визначення діяльності інформаційних служб системи МВС України щодо профілактики правопорушень.

Виклад основного матеріалу. Одним із головних завдань Міністерства внутрішніх справ $є$ створення якісно нової української поліції, яка б відповідала сучасним світовим стандартам. Партнерські стосунки між поліцією та населенням дістали новий імпульс до розвитку. Основним методом діяльності поліції щодо забезпечення громадського порядку є метод переконання. Суть його полягає у впливі на свідомість та поведінку людей з метою формування у них правильних переконань, розуміння необхідності добровільно і сумлінно виконувати вимоги закону та інших правових норм, а зміст становить комплекс різноманітних конкретних заходів і засобів такого впливу [3, с. 4].

У практичній діяльності поліції цей метод реалізується в різних формах, таких як: правове виховання; постійне інформування населення про стан боротьби з правопорушеннями; агітаційно-роз'яснювальна робота серед населення; застосування заходів заохочення; робота з правопорушниками, особами з так званих груп ризику [4, с.20].

y процесі взаємодії 3 населенням і засобами масової інформації головна увага зосереджена на координації профілактичної діяльності служб і підрозділів правоохоронних органів інформаційними службами МВС. Під координацією розуміється узгодженість дій правоохоронних органів у боротьбі з правопорушеннями за метою, часом, місцем проведення та програмою з урахуванням компетенції кожного з цих органів щодо вирішення спільних завдань у боротьбі з правопорушеннями в умовах їх функціонального зв'язку [5].

Так, як зазначає В. Л. Регульський, практика підказує, що координація і взаємодія забезпечують насамперед комплексний підхід до вирішення таких важливих питань, як пропаганда і роз'яснення населенню через засоби масової інформації ситуації, що склалась. А. В. Харламов підкреслює: «Керівники служб виступають у пресі, по радіо, телебаченню. Ми добре розуміємо, що вести боротьбу з цим небезпечним злом нам самим не під силу. Потрібна широка підтримка народу, зацікавленість усієї громадськості, необхідний органічний комплекс змобілізованих дій» [6, с. 7].

План боротьби зі злочинністю включає також питання співробітництва поліцейських служб з місцевими органами влади і громадськістю. Ці плани передбачають обмін інформацією, вони можуть бути використані для коригування і доповнення завдань з боротьби зі злочинністю на всіх рівнях $[7$, с. 11]. Усе це зумовлює необхідність активізації профілактики правопорушень, оновлення її форм і методів відповідно до нових соціально-економічних умов у країні. Профілактика правопорушень повинна відбуватися шляхом узгодженого та координованого здійснення комплексу заходів, передбачених відповідною комплексною програмою.

Поставлена мета досягається вирішенням низки завдань, які є загальними для всіх органів, що беруть участь у координації, і випливають із законів України, Указів Президента, Постанов Уряду України, наказів, розпоряджень МВС України та рішень його Колегії. До таких завдань слід віднести: розширення рівня гласності з метою підвищення авторитету правоохоронних органів, зміцнення їхньої репутації; об'єднання зусиль підрозділів поліції, усунення їх роз’єднаності в боротьбі з правопорушеннями з використанням засобів масової інформації; усунення розпорошення сил у діяльності правоохоронних органів щодо запобігання правопорушенням [8, с. 36].

У сучасних умовах значно зростає значення діяльності інформаційних служб MBC як серед населення, у засобах масової інформації, так і в службах та підрозділах 
правоохоронних органів. До того ж координаційна діяльність інформаційних служб МВС сприяє зміцненню законності і в самих правоохоронних органах, оскільки поліпшується можливість одержувати інформацію про її стан від третіх осіб [9, с. 246].

Організаційні принципи, за якими координаційна діяльність інформаційних служб MBC буде найбільш успішною: централізоване керівництво координаційною діяльністю як частиною діяльності 3 боротьби 3 правопорушеннями; узгодженість дій у досягненні мети і завдань щодо боротьби з правопорушеннями, спільних для всіх цих органів; рівність усіх учасників в обговоренні і наданні пропозицій для розроблення рекомендацій; самостійність кожного органу в здійсненні прийнятих рекомендацій; невтручання одних органів у виключну компетенцію інших [10].

Організація координаційної діяльності на основі перерахованих принципів дозволить виключити можливість підміни одних органів іншими, буде сприяти активізації й ефективності цієї діяльності. До основних рис цієї діяльності у сфері профілактики правопорушень слід віднести: право і обов'язок координуючого органу виявити ініціативу в питанні про узгодженість зусиль; обов'язок координованих органів - взяти участь в узгодженні; обов'язок координуючого органу створити, забезпечити організаційні умови узгодження (скликати, організувати обмін думками тощо); обов'язок координованих органів - використовувати ці умови і зробити все необхідне для узгодження заходів, що вживаються; право і обов'язок координуючого органу контролювати хід виконання узгоджених заходів [11, с. 103].

Для правильного налагодження координаційної діяльності велике значення має визначення системи іiї головних, взаємозалежних компонентів, якими повинні бути: зміст, організація, процедура, елементи, що входять до їх складу. Вони повинні відбивати найважливіші сторони узгодженої діяльності, тому необхідно позначити елементи цих компонентів.

Складовими елементами змісту є:

- Визначення цілей узгодженої діяльності щодо боротьби з правопорушеннями. Вони передбачають стратегічні напрями діяльності та шляхи їх реалізації. На цьому етапі не ставиться мета деталізації діяльності, її детальної регламентації. Як правило, це процес постановки загальних завдань. Тактичний бік питання вносить у процес координації конкретизацію, визначену форму та наповнює її конкретним змістом. Цей бік регламентується різноманітними програмами, наказами МВС України, розпорядженнями тощо.

- Планування узгодженої діяльності узгоджується з елементами процедури координації: порядок підготовки пропозицій для планування; процес розробки планів узгоджених заходів; визначення характеру заходів; контроль і перевірка результативності окремих заходів [12, с. 14].

Напрями координаційної діяльності інформаційних служб МВС визначаються, виходячи $з$ поставлених цілей. Вони конкретизують цю діяльність, надають їй цілеспрямованості, а це дозволяє одержати велику віддачу в боротьбі з правопорушеннями. Напрямки координаційної діяльності зумовлюються результатами аналізу стану правопорушень та заходів для зміцнення законності. Такими напрямами можуть бути:

- боротьба з правопорушеннями на території адміністративних одиниць (район, область тощо). Це доцільно в тих випадках, коли структура правопорушень не має різких коливань і вони територіально розподілені більш-менш рівномірно;

- боротьба з правопорушеннями в окремих населених пунктах (промислове місто, обласний центр, селище). Маються на увазі такі пункти, де правопорушення набули певного поширення;

- боротьба з окремими видами правопорушень, що набули поширення в даний період (сезонні правопорушення, за їх спрямованістю тощо). Цей напрям може поєднуватися з попередніми, якщо результати аналізу свідчать про поширення цих правопорушень у даних населених пунктах;

- боротьба $з$ правопорушеннями окремих категорій населення, що найчастіше вчиняють правопорушення (зокрема, осіб, які ведуть антигромадський спосіб життя, посадових осіб, неповнолітніх). Цей напрям у разі необхідності також може поєднуватися з попередніми [13, с. 103].

Інформаційним службам МВС у взаємодії з іншими підрозділами у веденні ефективної профілактичної роботи доцільно використовувати такі інструменти: спостереження за виконанням кримінального і адміністративного законодавства шляхом участі в інспектуваннях, несення служби в складах оперативних груп, спостереження під час проведення оперативно-слідчих і судових процедур; фінансові стимули для заохочення законослухняної поведінки, активної позиції громадян у розкритті злочинів, активу громадських та інших організацій і закладів, що надають допомогу в правовій пропаганді; соціальні інструменти, у тому числі комунікація, для змушення цільових груп нести 
відповідальність за дотримання законодавства України (оперативно-слідчі, судовопроцесуальні, морально-психологічні тощо [14, c. 250].

Навчання, як один з компонентів комунікації, може стимулювати цей процес і допомогти різноманітним прошаркам населення зрозуміти необхідність нетерпимості до правопорушень як явища та правопорушників. Якщо за мету береться зміна ставлення або поведінки (як суб'єктів, так і об'єктів), то використання методів комунікації поряд 3 іншими інструментами правоохоронної політики підвищує можливість успіху. Працівники інформаційних служб МВС повинні ширше використовувати потенціал, який надає координація діяльності правоохоронних підрозділів у взаємодії з громадськістю, трудовими колективами, засобами масової інформації з метою профілактики правопорушень. Так, наприклад, можливе спільне виконання профілактичної роботи слідчими й інформаційними службами МВС не процесуальним шляхом. У кожній резонансній справі виявляються причини вчинення злочину, умови, що сприяють цьому. Важливим етапом $є$ внесення подання про необхідність усунення причин і умов, що сприяли вчиненню злочинів, тій організації, підприємству, де вчинено злочин, або працівник якого став злочинцем. Зрозуміло, рекомендації, що містяться в поданні, не можуть і не повинні зв'язувати тих, хто буде проводити відповідні заходи. На широку участь слідчих необхідно звернути увагу працівникам інформаційних служб тоді, коли вони організовують спеціальні сторінки в пресі, рубрики на телебаченні та радіо на кшталт «Запитання - відповіді». Потрібно максимально використовувати досвід і знання слідчих для надання юридичних порад, коментування статей законодавства, підготовки тематичних рубрик про засоби вчинення злочинів, рекомендацій для громадян щодо уникнення злочинних нападів тощо [15, с. 125$]$.

При реалізації правоохоронної політики роль комунікації зводиться до постановки питання охорони громадського порядку. Уже на цій стадії велику роль відіграють громадські організації, як ті, що безпосередньо пов'язані з охороною порядку, так і ті, що за своїм змістом безпосередньо не пов'язані з цією діяльністю, а також різноманітні установи і організації, як державні, так і недержавні. Необхідно прислухатися до громадської думки, тому що в такий спосіб оперативно виявляються проблеми і виокремлюються спеціальні питання, що впливають на поведінку цільових груп і правоохоронну політику в цілому. На цій стадії комунікація - це спілкування працівників інформаційних служб МВС, служб та підрозділів правоохоронних органів з лідерами організацій, які формують громадську думку, де їхня увага звертається на питання, що потребують негайного вирішення, мобілізацію підтримки і визначення актуальних тем для обговорення. Це можуть бути регулярні зустрічі з лідерами політичних партій, громадських рухів, організацій з метою зближення позицій з питань правоохоронної діяльності, вироблення спільних підходів до розв'язання проблем боротьби з правопорушеннями, зміцнення ділових зв'язків $з$ державними організаціями та підприємствами для вироблення спільних (комплексних) програм боротьби з правопорушеннями.

На стадії ідентифікації правоохоронних проблем методами комунікації можуть бути:

- Вивчення громадської думки. Ця робота має два головних напрями. Перший - аналіз змісту повідомлень засобів масової інформації має значення для вироблення тактики і стратегії в подальших відносинах з окремими журналістами і засобами масової інформації в цілому. Другий - інформаційними службами МВС щодня в межах періодичних видань відстежуються і враховуються критичні матеріали щодо діяльності правоохоронних органів. Найбільший профілактичний ефект від таких виступів $€$ тоді, коли вони мають певний узагальнюючий характер, орієнтують на усунення типових криміногенних факторів. Відповідно до вимог Закону України «Про Національну поліцію» правоохоронні органи повинні інформувати трудові колективи, громадські організації, населення про свою діяльність, стан громадського порядку та заходи для його зміцнення. Важливим напрямом цієї роботи є організація й проведення виступів працівників поліції в трудових колективах підприємств, установ, організацій та за місцем проживання громадян [16].

- Проведення брифінгів, інтерв’ю, зустрічей із групами за інтересами і засобами масової інформації. Брифінг або пресконференція - ефективна форма взаємодії із засобами масової інформації, що дає можливість охопити максимальну кількість видань, редакцій, телебачення тощо. Проводяться брифінги щомісяця. До участі в брифінгу запрошуються представники всіх регіональних видань, телебачення і радіо, власники центральних інформаційних агентств і засобів масової інформації.

Комунікаційна діяльність інформаційних служб МВС може сприяти підвищенню розуміння громадськістю проблем правоохоронної діяльності, створити широку підтримку 
3 цих питань. Тут маються на увазі проблеми, які вже визнані органами державної влади актуальними, але які ще не мають реальних шляхів вирішення через різноманітні обставини, відсутність усіх складників соціальнополітичних умов, технічних можливостей тощо. Працівники інформаційних служб MBC повинні вибирати такі напрями роботи в службах і підрозділах, щоб уміти дати своєчасну оцінку подіям, що відбуваються в країні та регіоні (стан наукового потенціалу, досліджень і напрацювань, аналіз місцевої ситуації, прогнозування подій тощо).

Варто мати на увазі, що в процесі застосування принципів комунікації величезне значення мають три аспекти: посилена увага до виконання простих рішень; розширення набору інструментів у тих сферах правоохоронної політики, де реалізація завдань є складною; збалансоване вироблення та споживання. Зазначені аспекти визначають умови, в яких цільові групи безпосередньо стикаються 3 відповідальністю. Це означає перехід по вертикалі від регуляції до саморегуляції [17].

\section{Висновки.}

Національна поліція України шукає нові форми і засоби взаємодії та залучення громадськості до охорони громадського порядку та профілактичної роботи. Передбачені заходи дозволяють піднести на новий рівень партнерські стосунки між поліцією і населенням, налагодити ділове співробітництво між ними, створити організаційно-правову систему для більш широкого залучення громадськості до охорони громадського порядку та профілактичної роботи, сприяють підвищенню авторитету працівників поліції та своєчасному інформуванню населення через засоби масової інформації про їхню діяльність. Департамент комунікації МВС України, звітуючи перед громадськістю, може засвідчити: діяльність правоохоронців щодо припинення насильства в країні та допомога населення сприяли тому, що оперативна обстановка перебуває під контролем поліції.

\section{Список використаних джерел:}

1. Шубкін В. Про конкретні дослідження соціальних процесів. Комуніст. 1965. № 3. С. 53.

2. Пилипко А. Формула вирішення управлінських завдань - марево чи реальність. Право України. 2005. № 8. С. 118-121.

3. Битяк Ю.П., Зуй В.В., Комзюк А.Т. Переконання і примус у державному управлінні. Aдміністративна відповідальність: Конспекти лекцій. Харків: Укр. юрид. акад., 1994. 44 с.

4. Комзюк А.Т. Заходи адміністративного примусу: Поняття, види та організаційно-правові питання реалізації : монографія / за заг. ред. проф. О.М. Бандурки. Харків: вид-во Нац. ун-ту внутр. справ, 2002. $336 \mathrm{c.}$

5. Департамент комунікації Національної поліції України. Офіиіииний сайт НПу. URL: https://www.npu.gov.ua/uk/publish/article/ 1819839 (дата звернення: 16.03.2020).

6. Харламов А.В. У боротьбі зі злочинністю в сфері економіки потрібні чіткі орієнтири. Бюлетень по обміну досвідом роботи. Київ: МВС України, 1997. № 120. С. 7.

7. Организация и деятельность правоохранительных органов. Борьба с преступностью за рубежом по материалам зарубежной nрессы : Ежемесячный информационный бюллетень. Москва: АН России, 1994. № 11. С. 3-11.

8. Власюк В. Особливості взаємодії зі ЗМІ на прикладі нової патрульної поліції. Особливості взаємодї засобів масової інформачї з правоохоронними органами: міжнародний та начіональний досвід : матер. міжнар. круглого столу (23 лист. 2016 р., м. Київ). Київ: Національна академія прокуратури України, 2017. С. 35-37.

9. Мельничук Т.В. Взаємодія поліції та ЗМІ у протидії злочинам та правопорушенням. Одеські юридичні читання: матер. всеукр. наук.-практ. конфер. (м. Одеса, 10-11 лист. 2017 р.). Одеса: Видавничий дім «Гельветика», 2017. С. 244-248.

10. Положення про Департамент комунікації Національної поліції України : Наказ Національної поліції України від 04.12.2015 р. № 145. URL: https://www.npu.gov.ua/uk/publish/ article/1854459 (дата звернення: 14.11.2020).

11. Жалінський А.Е., Костицький В.М. Ефективність профілактики злочину та кримінологічна інформація. Львів, 1980. 212 с.

12. Взаємодія працівників Національної поліції з представниками ЗМІ під час несення служби: методичні рекомендації / Бугайчук К. Л., Сердюк О.О., Гладкова Є.О., Щербакова I.В., Баранник О.Б. Харків: Харк. нац. ун-т. внутр. справ., ГУНП України в Харк. обл. 2017. 26 с.

13. Вербицький П. Нормативно-правове забезпечення взаємодії журналістів 3 представниками влади в Україні. Держава та регіони. Серія «Соціальні комунікаиіi». Запоріжжя, 2016. № 28. С. 101-105.

14. Гуров А.И. Профессиональная преступность: прошлое и современность. Москва: Юрид.лит., 1990. 304 с.

15. Гуда Л. О. Окремі проблеми взаємодії підрозділів комунікації Національної поліції України із засобами масової інформації. Порівняльноаналітичне право. 2016. № 2. С. 125-127.

16. Про Національну поліцію : Закон України від 02.07.2015 № 580-VIII. Голос України. 2015. 06 серпня.

17. Соціологи Центру Разумкова зафіксували високий рівень довіри громадян до органів системи MBC. URL: https://mvs.gov.ua/ ua/news/18610_Sociologi_Centru_Razumkova_ zafiksuvali_vis okiy riven doviri gromadyan do_organiv_sistemi_MVS.htm ${ }^{-}$(дата звернення: 14.11.2020) 
Viktor Bulaiev. Activities of the information services of bodies of the MIA of Ukraine regarding crime prevention

Without broad public awareness of law enforcement and feedback, there can be no effective fight against crime, no high police authority among the population. Almost all state bodies within their competence take part in the management of social phenomena. It is impossible to consider their activities from the standpoint of a systematic approach in terms of coordination of efforts to prevent crime with access to mass coverage, because in this area of crime control they do not act as a single system, part of the subject of social management. The purpose of the article is to determine the organization of interaction of information services of the system of the Ministry of Internal Affairs of Ukraine with law enforcement agencies on crime prevention. As a result of an empirical study of the organization of interaction of information services of the Ministry of Internal Affairs of Ukraine with law enforcement agencies on crime prevention, it was determined that one of the main tasks of the Ministry of Internal Affairs is to create a qualitatively new Ukrainian police. The partnership between the police and the population has received a new impetus to development. The main method of police activity to ensure public order is the method of persuasion. Its essence is to influence the consciousness and behavior of people in order to form their correct beliefs, understanding the need to voluntarily and conscientiously comply with the law and other legal norms, and the content is a set of various specific measures and means of such influence. In the practice of police, this method is implemented in various forms: legal education; constant informing of the population about the state of fight against offenses; propaganda and explanatory work among the population; application of incentive measures; work with offenders, persons from so-called risk groups. The analysis of the organization of interaction of information services of the system of the Ministry of Internal Affairs of Ukraine with law enforcement agencies on crime prevention showed that in the process of interaction with the population and mass media the main attention is focused on coordination of preventive activities of law enforcement services. Coordination means the coordination of actions of law enforcement agencies in the fight against crime by purpose, time, place and program, taking into account the competence of each of these bodies, in solving common tasks in the fight against crime, in terms of their functional relationship. This goal is achieved by solving a number of tasks that are common to all bodies involved in coordination and follow from the lawes of Ukraine, Presidential Decrees, Resolutions of the Government of Ukraine, orders, directives of the Ministry of Internal Affairs of Ukraine and decisions of its Board. Such tasks should include: expanding the level of publicity in order to increase the authority of law enforcement agencies, strengthening their reputation; uniting the efforts of police units, eliminating their disunity in the fight against crime with the use of the media; elimination of the dispersion of forces in the activities of law enforcement agencies to prevent offenses.

Key words: information services, law enforcement units, crime prevention, mass media. 